\title{
Firm Survival: An Empirical Study Concerning Insurance Agencies
}

\author{
Andrea Lippi ${ }^{1}$, Laura Barbieri ${ }^{1}$, Ernestina Bosoni ${ }^{1} \&$ Anna Maria Fellegara ${ }^{1}$ \\ ${ }^{1}$ Department of Economic and Social Sciences, Università Cattolica del Sacro Cuore, Italy \\ Correspondence: Andrea Lippi, Department of Economic and Social Sciences, Università Cattolica del Sacro \\ Cuore, Italy. E-mail: andrea.lippi@unicatt.it
}

Received: August 11, 2019

doi:10.5539/ijbm.v14n11p101
Accepted: September 28, 2019

Online Published: October 9, 2019

\begin{abstract}
This paper analyzes the relevance of firm size, region, sales network, organizational structure, and auditing on the survival likelihood of a specific firm typology, the insurance agency. By applying a configurational comparative method, namely fuzzy-set qualitative analysis (fsQCA), to a unique dataset of 52 insurance agents, representing 52 active Italian insurance agencies, this study demonstrates that, when combined with other variables, organizational structure provides sufficient conditions for insurance agency survival. The different relevance of some specific management areas according to the insurance agency location is highlighted.
\end{abstract}

Keywords: firm survival, insurance agency, fsQCA, configurational comparative methods, firm's management areas

\section{Introduction}

In Italy, the insurance sector is characterized by the presence of thousands of insurance agencies throughout the country from the north to the south. Each insurance agency is an independent juridical entity and like any commercial enterprise, each of them has to face the problem of increasing competition, developing new distribution channels, and changes in consumer behavior. In a word, even insurance agencies have to face the survival problem.

The literature on firm survival is very extensive and considers different aspects and countries (e.g. Box 2008; Agarwal and Gort 2002; Klepper 2002; Tsoukas 2011; Chung et al. 2013; Bontemps et al. 2012; Paeleman et al. 2015; Guariglia et al. 2016; Huggins et al. 2017). However, the issue of survival in the insurance agency sector is absent from the literature. This paper intends to open a new field of research and fills the gap in the literature. The paper's originality is based on three main aspects: i) the insurance sector and in particular insurance agencies, completely neglected in the literature; ii) the factors considered in the analysis and iii) the unique dataset. Specifically, the factors examined for insurance agencies' survival concern important management areas for commercial companies, such as the sales network, internal auditing and organizational structure. Other factors such as firm size and region are also considered.

The database used in the analysis is a unique dataset. In 2011, 52 insurance agents, representing 52 active Italian insurance agencies, were asked to complete a questionnaire concerning the importance they attribute to specific management areas. In 2018 we checked how many agencies were still active and we examined the factors which had determined their survival.

In order to analyze this dataset and cope with the small sample size problem, we refer to the configurational comparative method devised by Ragin (1987) namely the fuzzy set qualitative comparative analysis (fsQCA), which has gain relevance over the last years in business and management research. fsQCA is a data analysis technique for determining which logical conclusions a dataset supports, combining detailed within-case analysis and formalized cross-case comparison. With respect to other traditional probability-based statistical techniques, fsQCA does not require large samples (limiting the study to a few cases or case studies), while still guaranteeing the general applicability of its conclusions or implications to a larger population. In addition, while traditional statistical techniques are good at drawing out the net effect of single variables, QCA is able to detect different conditions that lead to the same outcome.

\section{Literature Reviews and Hypotheses}

Bearing in mind the lack of literature on insurance agencies' survival, as well as on the relationship between 
management areas and company survival, this section contains a brief review of the literature considered relevant to our analysis. A number of studies have empirically evaluated the factors that influence the probability of firms' survival in the market. At firm level, these factors have traditionally been size and age of the firm, both increasing survival probability (Evans 1987; Dunne et al. 1989; Dunne and Hughes 1994; Cefis and Marsili 2006 and Fritsch et al. 2006). New firms' survival is also a topic considered in the literature. Many empirical studies at firm level have found that survival probability increases with firm size (Mata and Portugal 1994; Geroski 1995; Audretsch et al. 2000; Agarwal and Audretsch 2001).

Kalleberg and Leicht (1991) and Borghesi et al. (2007) analyze the relation between firms' survival and organizational structure. The former consider 441 companies in the computer sales and software, food and drink, and health indutries in South Central Indiana; the second consider a sample of 67,000 firms over the period 1981 to 2003, taking into account firm age, agency cost, survival and firm organizational decisions over time. Shane (1996), Tan and Peng (2003) and Wischnevsky (2004) highlight the fact that organizational structure is necessary to guarantee smooth company management, and rapidity in capturing market changes and coping with moments of crisis. Thus, organizational structure may influence firms' survival.

The relationship between sales networks and firms' survival is also considered in the literature. Winter et al. (2003) highlight the importance of sales networks by considering a sample of Korean furniture manufactures threatened by the financial downturn of 1997. Sepulveda and Gabrielsson (2013) develop a theoretical framework that links resource development and enterpreneurial orientation to network content, structure, centrality and management. In the business-to-business (B2B) context, Jones et al. (2013) find that firms use marketing and sales networks, among other factors, to create value for the firm. Firms' survival may therefore depend on the ability of the sales networks and their involvement and coordination (Reynolds 1987; Lee et al. 2012).

Walz (1997) demonstrates that internal auditors contribute to firms' survival through reduction in the cost of the internal function and through the introduction of audit recommendations that increase firm value. Gaeremynck and Willekens (2003) demonstrate the relationship between audit-report type and subsequent business termination for private companies in a non-litigious environment. According to the authors an endogenous relationship exists between bankruptcy and audit-report type. Jain and Martin Jr (2005) examine the relationship between audit quality and post-IPO survival. Karagiorgos et al. (2009) and Karagiorgos et al. (2011) test a hypothesis concerning the role of internal auditing in business success. According to these authors, internal auditing is vital for business survival and success.

Bearing in mind these findings reported in the literature, this study aims to test the following hypotheses:

Hypothesis 1 - Insurance agency survival increases in accordance with its size.

Hypothesis 2 - Insurance agency survival is linked to its organizational structure.

Hypothesis 3 - Insurance agency survival is linked to its sales network.

Hypothesis 4 - Insurance agency survival is linked to its internal auditing.

\section{Empirical Research}

\subsection{Data}

The database used in the analysis is a unique dataset. During 2011, 52 insurance agents, representing 52 active Italian insurance agencies belonging to a primary Italian national insurance agencies' association, were asked to complete a questionnaire regarding three specific management areas (sales network, auditing, and organizational structure). The aim of the questionnaire (see Appendix) was to test the level of awareness of the relevance of these management areas in business continuity. The score attributed to each answer was 1 for positive, 0 for negative and -1 for "I Don't know". 39 out of the 52 Italian insurance agencies were still active in 2018, whereas 13 were no longer going concerns. In terms of size, all the firms in the sample were either micro or small (in accordance with the European Commission recommendation, fewer than 10 and 50 employees respectively), because of the characteristics of this business in Italy.

\subsection{Methodology}

Configurational analysis is a multi-faceted approach, based mainly on set theory and Boolean algebra, which addresses configurations as varying case types in order to work out what combination of characteristics may be necessary or sufficient to produce a certain outcome. Comparative qualitative analysis (QCA) makes it possible to bridge the gap between qualitative (case study oriented) and quantitative (variable oriented) approaches, allowing the analysis of a small number of cases. This study uses a specific type of QCA, namely fuzzy set QCA 
(fsQCA), which allows for any value in the interval $[0,1]$ indicating partial (non)membership in a given set.

QCA follows some typical main steps. The first step is truth table construction, i.e. the construction of a table of all the logically possible combinations of the considered conditions (variables). In the second step, the number of rows in the truth table is reduced, considering only those combinations with a minimum consistency of 0.75 (Ragin, 2006). It is possible to highlight cases that lead to the outcome and drop cases where the outcome is not present. In the third step of analysis, the information contained in the truth table is restated in terms of a parsimonious and encompassing truth-functional proposition set.

The parsimonious solution takes into account all simplifying assumptions, both involving easy or difficult counterfactuals. At this stage of analysis the QCA results are written in a solution formula that logically summarizes the information contained in the truth table. The outcome and conditions are listed in Table 1.

Table 1. Outcome and conditions: description and codifications

\begin{tabular}{|c|c|c|}
\hline Outcome conditions & Description & Codification \\
\hline Outcome: survival & Dichotomous variable indicating firm survival for the period 2011-2018 & \\
\hline size & Continuous variable that specifies the number of employees & Fuzzy \\
\hline region & $\begin{array}{l}\text { Dichotomous variable indicating if the firm is in the Centre or South of } \\
\text { Italy (0) or in the North (1) }\end{array}$ & Crispy \\
\hline sales & $\begin{array}{l}\text { Continuous variable specifying the importance given to the sales network } \\
\text { area }\end{array}$ & Fuzzy \\
\hline organization & $\begin{array}{l}\text { Continuous variable specifying the importance given to the organizational } \\
\text { structure area }\end{array}$ & Fuzzy \\
\hline audit & Continuous variable specifying the importance given to the auditing area & Fuzzy \\
\hline
\end{tabular}

The outcome (i.e. survival) is a dichotomous variable distinguishing active firms from those that no longer exist. The conditions are firm size, region and the importance given to management areas (i.e. sales network, organizational structure and auditing). The measurement of firm size is as a fuzzyset condition depending on the number of employees: microenterprises (close to 0 ) and small firms (close to 1).

Region is a dichotomous condition, which establishes whether the firm is located in the Center or South of Italy (coding a firm as 1 , fully in this set) or in the North (coding a firm as 0 , outside the set).

Sales, org and audit are fuzzyset conditions specifying the relevance given to each management area - sales network, organizational structure and auditing - (coding a firm as 1, fully in this set and 0, outside the set).

\section{Results and Discussion}

This section presents results from the analysis of the conditions that lead firms to the outcome (i.e. survival). The model for analysis is:

$$
\text { survival }=f(\text { size, } \text { region, } \text {, sales, organization, } \text { audit })
$$

The first step in fsQCA is the analysis of necessary conditions, which is a separate procedure that looks at which individual factors may be necessary or mostly necessary for the outcome to occur. This entails that the membership score on the outcome be consistently lower than the membership score of the causal factor under consideration.

Table 2 shows the causal conditions relevant to the survival of the 52 agencies from 2011 to 2018, where the outcome of interest is the degree of membership in the set of agencies which survived in this period (survival).

Table 2. Necessary conditions analysis (outcome: survey).

\begin{tabular}{lll}
\hline & Consistency & Coverage \\
\hline sales & 0.418 & 0.816 \\
audit & 0.568 & 0.749 \\
organization & 0.755 & 0.788 \\
size & 0.877 & 0.739 \\
region & 0.667 & 0.765 \\
\hline
\end{tabular}


Consistency and coverage are the two key parameters for assessing the fit of results (Ragin, 2006). Consistency exceeds 0.75 only for the organization and size variables (see Table 2), meaning that only in these cases is there considerable consistency; coverage, which is a measure of how trivial or relevant a necessary condition is for the outcome, is always higher than 0.7 . One can argue that only organization and size are on their own able to assure survival, while the other conditions are not.

Table 3 presents the results of the sufficiency analysis, which indicates a set of sufficient relations between insurance agency survival and a certain subset of conditions. Analysis consistency is 0.850 , which indicates a sufficient relation between agency survival and these conditions.

Table 3. Sufficiency analysis results (outcome: survey)

\begin{tabular}{|c|c|c|c|}
\hline & Consistency & $\begin{array}{l}\text { Raw } \\
\text { coverage }\end{array}$ & $\begin{array}{l}\text { Unique } \\
\text { coverage }\end{array}$ \\
\hline sales $*$ audit $*$ organization $*$ region & 0.848 & 0.216 & 0.042 \\
\hline sales ${ }^{*}$ organization $* \sim$ size ${ }^{*}$ region & 0.844 & 0.218 & 0.044 \\
\hline$\sim$ sales $^{*} \sim$ audit $^{*}$ organization $* \sim$ size $* \sim$ region & 0.807 & 0.093 & 0.093 \\
\hline \multicolumn{4}{|l|}{ Solution coverage: 0.352} \\
\hline Solution consistency: 0.850 & & & \\
\hline
\end{tabular}

Note. Note that symbol represents the "negation" of the characteristic.

Table 3 indicates three solutions resulting from the analysis. The symbol $\sim$ represents the "negation" of the characteristic (e.g. " $\sim$ sales" is equal to "not sales"), while the symbol * represents the logical operator AND. Configurations connected by * are sufficient conditions to lead to survival. Each of the three configurations reaches the consistency threshold of 0.80 suggested by Ragin (2008).

The first configuration is sales*audit*organization*region, which shows that a combination of each management area considered in the survey (sales network, auditing, and organizational structure) with the insurance agency location in the center or south of Italy is a sufficient condition for its survival. The second configuration is sales*organization* size*region, which implies that sales network and organizational structure in a microenterprise located in the center or south of Italy represent a sufficient condition for insurance agency survival. Finally, $\sim$ sales* $\sim$ audit*organization $*$ size* $\sim$ region implies that micro-size insurance agencies located in the north of Italy have survived when mainly focused on organizational structure rather than on sales network and auditing area.

\section{Conclusions}

This study examines firm size, region, and some management areas (sales network, organizational structure, and auditing) which, according to the literature, may influence firm survival in general and therefore that of insurance agencies as well. The analysis employs fsQCA (Ragin, 1987) to identify combinations of conditions (causal configurations) that lead to insurance agency survival in Italy. fsQCA is based on the analysis of set relations, not correlations, and is a way to analyze problems where there are few observations and where the outcome depends on the configurations of some variables. This analysis technique has gain increasing prominence in social science over the last years.

The results obtained basing on a unique dataset of 52 Italian insurance agents highlight the fact that organizational structure in combination with other variables provides sufficient condition for insurance agencies' survival. In particular, a key implication of the analysis is that for microenterprises located in the north of Italy, the entrepreneurship policies of the chief insurance agent should emphasize organizational structure in order to increase the likelihood of survival. For insurance agencies located in the center or south of Italy, other management areas, such as sales network and auditing, play an important role together with organizational structure, in insurance agencies' survival irrespective of the firm size while, in the same region, for micro insurance agencies, organizational structure combined with sales network are relevant for their survival. Thus, organizational structure appears as more relavant than other management areas examined in this research.

This study has some limitations, which can constitute opportunities for future research. For instance, it could be interesting to examine the entrepreneurship policies implemented so as to improve a single management area, bearing in mind the geographical location of insurance agencies. Moreover, future research could investigate whether the distinction between North and Center/South of Italy is a distinctive condition for micro firms 
operating in other sectors in Italy.

\section{References}

Agarwal, R., \& Audretsch, D. (2001). Does entry size matter? The impact of the life cycle and technology on firm survival. The Journal of Industrial Economics, 49(1), 21-43. https://doi.org/10.1111/1467-6451.00136

Agarwal, R., \& Gort, M. (2002). Firm and product life cycles and firm survival. American Economic Review, 92(2), 184-190. https://doi.org/10.1257/000282802320189221

Audretsch, D. B., Houweling, P., \& Thurik, A. (2000). Firm survival in the Netherlands. Review of industrial organization, 16(1), 1-11. https://doi.org/10.1023/A:100782450

Bontemps, C., Bouamra-Mechemache, Z., \& Simioni, M. (2012). Quality labels and firm survival: some first empirical evidence. European Review of Agricultural Economics, 40(3), 413-439. https://doi.org/10.1093/erae/jbs034

Borghesi, R., Houston, J., \& Naranjo, A. (2007). Value, survival, and the evolution of firm organizational structure. Financial Management, 36(3), 5-31. https://doi.org/10.1111/j.1755-053X.2007.tb00078.x

Box, M. (2008). The death of firms: exploring the effects of environment and birth cohort on firm survival in Sweden. Small Business Economics, 31(4), 379-393. https://doi.org/10.1007/s11187-007-9061-2

Cefis, E., \& Marsili, O. (2006). Survivor: The role of innovation in firms' survival. Research Policy, 35(5), 626-641. https://doi.org/10.1016/j.respol.2006.02.006

Chung, Y. P., Seung, N. H., \& Smith, R. (2013). How important is capital structure policy to firm survival? Journal of Corporate Finance, 22, 83-103. https://doi.org/10.1016/j.jcorpfin.2013.04.002

Dunne, P., \& Hughes, A. (1994). Age, size, growth and survival: UK companies in the 1980s. The Journal of Industrial Economics, 42(2), 115-140.

Dunne, T., Roberts, M., \& Samuelson, L. (1989). The growth and failure of US manufacturing plants. The Quarterly Journal of Economics, 104(4), 671-698. https://doi.org/10.2307/2937862

Evans, D. S. (1987). The relationship between firm growth, size, and age: Estimates for 100 manufacturing industries. The journal of industrial economics, 35(4), 567-581.

Fritsch, M., Brixy, U., \& Falck, O. (2006). The effect of industry, region, and time on new business survival-a multi-dimensional analysis. Review of industrial organization, 28(3), 285-306. https://doi.org/10.1007/s11151-006-0018-4

Gaeremynck, A., \& Willekens, M. (2003). The endogenous relationship between audit-report type and business termination: Evidence on private firms in a non-litigious environment. Accounting and Business Research, 33(1), 65-79. https://doi.org/10.1080/00014788.2003.9729632

Geroski, P. (1995). What do we know about entry? International Journal of Industrial Organization, 13(4), 421-440. https://doi.org/10.1016/0167-7187(95)00498-X

Guariglia, A., Spaliara, M., \& Tsoukas, S. (2016). To what extent does the interest burden affect firm survival? Evidence from a panel of UK firms during the recent financial crisis. Oxford Bulletin of Economics and Statistics, 78(4), 576-594. https://doi.org/10.1111/obes.12120

Huggins, R., Prokop, D., \& Thompson, P. (2017). Entrepreneurship and the determinants of firm survival within regions: human capital, growth motivation and locational conditions. Entrepreneurship \& Regional Development, 29(3-4). https://doi.org/357-389. 10.1080/08985626.2016.1271830

Jain, B., \& Martin Jr, C. (2005). The association between audit quality and post-IPO performance: A survival analysis approach. Review of Accounting and Finance, 4(4), 50-75. https://doi.org/10.1108/eb043437

Jones, R., Suoranta, M., \& Rowley, J. (2013). Strategic network marketing in technology SMEs. Journal of Marketing Management, 29(5-6), 671-697. https://doi.org/10.1080/0267257X.2013.797920

Kalleberg, A., \& Leicht, K. (1991). Gender and organizational performance: Determinants of small business survival and success. Academy of Management Journal, 34(1), 136-161. https://doi.org/ 10.5465/256305

Karagiorgos, T., Drogalas, G., \& Giovanis, N. (2011). Evaluation of the effectiveness of internal audit in Greek Hotel Business. International Journal of Economic Sciences and Applied Research, 4(1), 19-34.

Karagiorgos, T., Drogalas, G., Eleftheriadis, I., \& Christodoulou, P. (2009). Efficient risk management and internal audit. International Journal of Management Research and Technology, 3(2), 429-436. 
Katz, D. A. (1978). The social psychology of organizations. New York: Wiley.

Klepper, S. (2002). Firm survival and the evolution of oligopoly. RAND journal of Economics, 33(1), 37-61. https://doi.org/10.2307/2696374

Lee, H., Kelley, D., Lee, J., \& Lee, S. (2012). SME survival: The impact of internationalization, technology resources, and alliances. Journal of Small Business Management, 50(1), 1-19. https://doi.org/10.1111/j.1540-627X.2011.00341.x

Lin, X. (2007). Chinese entrepreneurs in network marketing organizations: a culture-moderated social capital perspective. Journal of Small Business \& Entrepreneurship, 20(3), 273-288. https://doi.org/10.1080/08276331.2007.10593400

Mata, J., \& Portugal, P. (1994). Life duration of new firms. The journal of Industrial Economics, 42(3), 227-245. https://doi.org/10.2307/2950567

Paeleman, I., \& Vanacker, T. (2015). Less is more, or not? On the interplay between bundles of slack resources, firm performance and firm survival. Journal of Management Studies, 52(6), 819-848. https://doi.org/10.1111/joms.12135

Ragin, C. C. (2006). How to lure analytic social science out of the doldrums: Some lessons from comparative research. International Sociology, 21(5), 633-646. https://doi.org/ 10.1177/0268580906067834

Ragin, C. C. (2008). Redesigning social inquiry: Fuzzy sets and beyond. University of Chicago Press.

Reynolds, P. (1987). New firms: Societal contribution versus survival potential. Journal of Business Venturing, 2(3), 231-246. https://doi.org/10.1016/0883-9026(87)90011-5

Sepulveda, F., \& Gabrielsson, M. (2013). Network development and firm growth: A resource-based study of B2B Born Globals. Industrial Marketing Management, 42(5), 792-804. https://doi.org/10.1016/j.indmarman.2013.01.001

Shane, S. (1996). Hybrid organizational arrangements and their implications for firm growth and survival: A study of new franchisors. Academy of Management Journal, 39(1), 216-234. https://doi.org/ $10.5465 / 256637$

Tan, J., \& Peng, M. W. (2003). Organizational slack and firm performance during economic transitions: Two studies from an emerging economy. Strategic Management Journal, 24(13), 1249-1263. https://doi.org/10.1002/smj.351

Tsoukas, S. (2011). Firm survival and financial development: Evidence from a panel of emerging Asian economies. Journal of Banking \& Finance, 35(7), 1736-1752. https://doi.org/ 10.1016/j.jbankfin.2010.12.008

Walz, A. (1997). Adding Value: Creating value has become a matter of survival. Internal Auditor, 54(1), 51-55.

Winter, G., McIntosh, J., \& May, D. (2003). Survival in the Korean Furniture Industry: Value-chain Networking. Journal of Managerial Issues, 15(4), 450-466. https://doi.org/www.jstor.org/stable/40604445

Wischnevsky, J. D. (2004). Change as the winds change: The impact of organizational transformation on firm survival in a shifting enviroment. Organizational Analysis, 12(4), 361-377. 


\section{Appendix}

Dear Agent,

This questionnaire is a tool used for research purposes to collect information about some management areas of the insurance agency you work for. Please fill in the preliminary information and then put an $X$ in the appropriate box ('Yes'; 'No'; 'I don't know'). Please complete it carefully and return it in the sealable envelope attached. Thank you in advance for your cooperation.

\section{Preliminary information}

Your insurance agency is located in: north of Italy

center/south of Italy

Agency name:

$\mathrm{N}^{\circ}$ of employees/agents in your agency:

\section{Management area questions}

\begin{tabular}{lrr}
\hline ORGANIZATIONAL STRUCTURE AREA & YES NO $\begin{array}{r}\text { IDON'T } \\
\text { KNOW }\end{array}$ \\
\hline
\end{tabular}

Do the insurance agency's administrative employees have knowledge of each others' jobs and responsibilities?

Has the insurance agency adopted its own set of forms (insurance company forms excluded), used by all its employees?

Are all the purchases made by the insurance agency always regulated, authorized and monitored?

Have procedures that describe processes and job activities been formalized in the insurance agency?

Does the insurance agency have an organization chart?

Are other training activities periodically organized for the administrative employees, in addition to legally-required ones?

Does each employee have a personal access password to the computer system, according to his job position and responsibilities?

Does everybody know about and comply with safety requirements?

Do the working procedures, organization and operations of the insurance agency ensure compliance with privacy requirements?

Can you say for sure that the agency's server is well organized in terms of folders and files?

Do all the insurance agency employees have good computer skills?

Does the insurance agency have an IT specialist?

Can the employees resolve easy IT problems (mouse, toner etc.)?

Does the insurance agency have customized computer programs for specific tasks?

Is data backup carried out regularly?

Are the passwords used for home banking payments well shielded?

Have you checked whether the insurance company software satisfies all the agency's requirements?

\begin{tabular}{lr} 
SALES NETWORK AREA & I DON'T \\
\hline
\end{tabular}

Does the insurance agency have specific software tools that help with the storing of all the sales team's information, in particular scheduled and other work deadlines/appointments?

Does the insurance agency have specific software tools that help with the storing of all the insurer's information with regard to potential customers' personal data?

Does the sales team have an organization chart that defines roles and responsibilities?

In the insurance agent's opinion, is the turnover of the sales team within an acceptable range?

Is the situation of each insurance contract processed by individual agents periodically checked?

Is the insurance agent aware of his fees and benefits?

Did the insurance agent organize his sales network so that he can work out the profitability of each subagent?

Did the insurance agent organize his sales network so that he can work out the profitability of each sub-agency?

Did the insurance agent organize his sales network so that he can work out the profitability of the broker 
network?

Does the insurance agency have all the necessary information to check if insurance policy redemption is within an acceptable range?

Do the insurance agent and his sales team analyze customers' needs and expectations?

Can the insurance agency quickly adapt itself to customers' needs and expectations?

"You can always improve": are training activities for sales network staff periodically planned, in addition to compulsory ones?

\begin{tabular}{lr} 
AUDITING AREA & I DON'T \\
& YES NO \\
\hline
\end{tabular}

When the insurance agent prepares the agency's annual budget, is he aware of the agency's affordable fixed costs?

Is the monthly active commissions trend constantly and closely monitored?

Does the insurance agent check the monthly trend of receipts generated by insurance contracts (premiums)?

Does the insurance agent have all the instruments and knowledge necessary to evaluate the profitability of the life and non-life assurance sectors?

Is a financial forecast (costs and revenues) consistent with the sales forecast prepared every year?

Are differences between the actual and expected values of the income statement periodically analyzed?

Are periodical budgets drawn up?

Is a sales forecast drawn up at the beginning of the year?

Does the insurance agent know the breakdown of the agency's fixed costs?

Does the insurance agent intervene regarding the agency's fixed cost items during the year?

Is the impact of possible modifications in costs made by the insurance agent checked during the year?

Can the insurance agent use incentives throughout the year that could modify the structure of the agency's variable costs (e.g. passive fees)?)?

Does the insurance agent know the percentage of passive commissions for each sector (life and non-life assurance)

Are bank and other credit companies' contract terms periodically renegotiated?

Does the insurance agent have all the information necessary to check if total sales costs (fixed and variable) have increased, compared to those of the previous year?

Does the insurance agent have all the necessary information to check if the structure of the sales costs of the agency has changed?

Does the insurance agent know the break-even point of his agency?

Is the balance sheet periodically classified so that it can be helpful for management purposes?

\section{Copyrights}

Copyright for this article is retained by the author(s), with first publication rights granted to the journal.

This is an open-access article distributed under the terms and conditions of the Creative Commons Attribution license (http://creativecommons.org/licenses/by/4.0/). 